\title{
a EDUCaÇão para a saúde: O CLIENTE COMO SUJEITO DA AÇĀo*
}

\author{
Maria Teresa C. Lagana**:
}

LAGANÁ, M. T. C. A educaçāo para a saúde: o cliente como sujeito da açāo. Rev. Esc. Enf. USP. São Paulo, 23(1):-, abr. 1989.

A autora apresenta algumas consideraçöes sobre a educaçāo para a saúde na perspectiva do processo saúde doença onde o significado de educar é diferente na educaf̧âo tradicional e no contexto do materialismo historico.

UNITERMOS: Educação em saúde. Saúde e doença.

\section{INTRODUÇÃO}

A despeito dos recursos tecnológicos e científicos de que dispomos hoje em dia, a população continua com déficit de atenção à saúde, fazendo-nos crer que temos sido ińcuos na tentativa de interferir nos problemas de saude das comunidades, principalmente se observarmos as estatísticas epidemiologicas gerais do pars. Ainda que existam decisōes fundamentalmente políticas, como a implantaçāo de mudanças no Sistema de Saúde, o controle das diarréias através de saneamento básico ou a diminuição da desnutriçāo através de um aumento da renda per capita, a adequação da prática de enfermagem às necessidades de saúde da população, converge, em grande parte, para a questāo educativa. Porém, o hábito dos profissionais de saúde exencerem o assistencialismo, os leva a tolher a consciência e a capacidade de reflexāo daqueles que procuram alguma forma de assistência.

\section{A EDUCAÇĀo PARA A SAÚdE SOB O PONTO DE VISTA TRADICIONAL}

Tradicionalmente a educação para a saúde tem se caracterizado pelos modelos industriais de desenvolvimento, empregando māo-de-obra especializada para educar a populaçāo mal-orientada, dando à educação um cunho paternalista e autoritário que se traduz pelo assistencialismo. No entanto, a maioria da populaçäo continua a manter comportamentos indesejáveis sob o ponto de vista de seu bem-estar, como o hábito do fumo, do alcoolismo, do desmame precoce, do consumo excessivo de alimentos e medicamentos alopáticos ou do descaso com o auto

- Parte da monografia de mestrado apresentada à Escola de Enfermagem da USP. Sso Paulo, 1986.

** Enfermeira. Mestre em Enfermagem. Professor Assistente do Departamento de Enfermagem MedicoCirárgica da Escola de Enfermagem da USP. Disciplinas Introduço e Fundamentos de Enfermagem. 
cuidado, ou seja, a educaçāo tem estado desvinculada da situação social e cultural das comunidades.

A concepçāo técnica dos profissionais de saúde que têm como referencial os países em desenvolvimento, acerca das razōes que dificultam a concretização da educação para a saúde, gira em torno:

. da baixa renda económica da maioria da população que propicia um baixo nível tecnológico da famnlia;

- da precária formação educacional, geral e sanitária da população;

- da deficiência em competência das pessoas que é manifestada pela sua incapacidade em vigiar a própria saúde;

- de a maioria dos agentes das ações de saúde do setor de enfermagem no Brasil não ter preparo adequado e

. do fato das técnicas educativas atualmente utilizadas no setor de saúde precisarem ser melhoradas.

Mas, em verdade, essas colocaçōes são muito influenciadas pelos dogmas habituais do Sistema de Saúde que encaram a cultura ou o modo das pessoas estarem no mundo como uma configuração de padrōes de comportamento que somente dão sentido e valor às coisas desde qua adaptadas aos padrōes idealizados pelas classes dominantes da elite de saúde. Os aspectos referidos não podem, por si só, serem determinantes do atual estado de déficit educacional da população em seus vários aspectos, uma vez que a coloca como mero receptáculo de fatores que a oprime e a encara como seres dependentes de orientaçāo técnica para sobreviverem. Se a educaçāo para a saúde tem sido difícil até então é porque tem estado descinvulada da realidade concreta da população e não porque esta não possa e, principalmente, näo queira buscar comportamentos que the tragam saúde e bem estar.

O processo educativo é por demais complexo e por isso nāo pode ser encarado de maneira tão simplista, uma vez que é o próprio homem o criador de sua cultura, ao transformar, ele próprio, a sua realidade natural de vida.

\section{A EDUCAÇĀO PARA A SAÚDE SOB O PONTO DE VISTA DO MATERIALISMO HISTÓRICO}

A educação para a saúde, sob o ponto de vista do materialismo histórico, não considera o homem simplesmente como (resultado de) um produto biológico e que, como tal, deva ser tratado clinicamente, mas o encara como um agente do processo saúde-doença, considerando o meio ambiente em que ele vive como história concreta, acontecendo num enfoque mais coletivo das condiçōes de saúde, muitas vezes determinado socialmente. 
As necessidades humanas básicas, sob esse prisma, refletem uma condição do homem extremamente vulnerável aos acontecimentos do mundo, sugerindo a idéia de que a açăo oducativa deve incidir de forma reflexiva e dentro do universo cultural com quem se compartilha o aprendizado. Portanto, se o enfermeiro quiser, eficazmente, atender a homem, deve observar as nocessidades que ele prioriza para si porque os acontecimentos sociais refletem claramente que a saúde está determinada historicamente. LAURELL(1) afirma que o processo saúde doença é determinado pelo modo como o homem se apropria da natureza em um dado momento, apropriaçāo que se realiza por meio do processo de trabalho, baseada em determinado desenvolvimento das forças produtoras e relações sociais de produção.

\section{O CLIENTE COMO SUJEITO DA AÇĀO}

Num processo educacional reflexivo todas as etapas evolutivas das experiências vividas pelas pessoas têm que ser consideradas como potencialmente capazes de causar modificaçōes na estrutura do pensar-agir delas e, portanto, a educação deve partir justamente dessas vivências pessoais, guiada, apenas, pelo conhecimento técnico do profissional. Uma vez que é proporcionada às pessoas a oportunidade de discutirem sobre sua atividade diária de vida ou de trabalho, elas sāo capazes de refletir sobre suas experiências e buscar a dimensão de sua própria vida em sua prática de trabalho. Elas são capazes de passar as significaçōes de suas experiências para contextos mais gerais como o social e o econômico e não mais de forma pragmática ou utilitária. Tomam consciência das relaçōes sociais de dominaçāo extrapoladas para todos os segmentos das suas vidas. À medida que refletem sobre sua vida e seu trabalho, sentem-se mais capazes de serem o que são, tomando ciência da sua condição humana e social, adquirindo forças e se posicionando frente ao mundo, motivadas pela compreensão da situação em que se encontram.

\section{CONCLUSĀO}

A educaçāo que provoca um processo de conflito interior nas pessoas é capaz de gerar oportunidades de aprendizado muito mais intensas porque é difícil pensar as próprias atitudes sem repensar o conjunto das práticas sociais das quais fazem parte. Dessa forma consegue-se evitar que a população continue entendendo o processo saude-doença como um acontecimento natural, de uma linearidade impossível de ser interrompida.

O profissional da saúde, a partir do velho chavão com o qual costuma retratar a populaçāo de "carente" forçosamente será levado a questionar: mas, carente de que?. Será ele capaz de identificar os níveis de sua açāo no processo saúde- 
doença sem passar os indíviduos do grupo doente para o grupo sadio apenas sob uma açăo prescritiva do médico?

É evidente que essa nova prática oducativa é útil e necessária para o proprio profissional, uma vez que o força a refletir sobre a utilizaçāo habitual de conceitos oportunistas ao discutir superficialmente as palavras, desvinculadas da sua realidade assistencial. Essa superficialidade com que trata da sua prótica não o leva a refletir sobre ela e, portanto, a transformá-la, a nāo ser que ele se proponha a ser educado justamente pela ação recfproca da reflexāo das pessoas, seus clientes, sobre seus proprios referenciais históricos e não mais como um profissional depositário do saber.

LAGANA, M. T. C. Education for health: the client as the Subject of action. Rev. Esc. Enf. USP, São Paulo, 23(1):-, Apr. 1989.

The author make some considerations on the education for health based on the health-illness process view-point, where the significance of education is different in the traditional education and in the historical materialism context.

UNTTERMS: Health education. Health and disease.

\section{REFERÊNCIAS BIBLIOGRÁFICAS}

1. LAURELL, A, C. La salud-enfermedad como proceso social. Rev. Latinoam. Salud, México, 2:7$25,1982$. 